Wright State University

CORE Scholar

1995

\title{
The Future Using an Integrated Approach: The OhioLINK Experience
}

Phyllis O'Connor

Susan Wehmeyer

Wright State University - Main Campus, susan.wehmeyer@wright.edu

Susan Weldon

Wright State University - Main Campus

Follow this and additional works at: https://corescholar.libraries.wright.edu/ul_pub

Part of the Library and Information Science Commons

\section{Repository Citation}

O'Connor, P., Wehmeyer, S., \& Weldon, S. (1995). The Future Using an Integrated Approach: The OhioLINK Experience. The Journal of Library Administration, 20 (1/2), 109-120.

https://corescholar.libraries.wright.edu/ul_pub/143

This Article is brought to you for free and open access by the University Libraries at CORE Scholar. It has been accepted for inclusion in University Libraries' Staff Publications by an authorized administrator of CORE Scholar. For more information, please contact library-corescholar@wright.edu. 


\section{The Future Using an Integrated Approach:}

\section{The OhioLINK Experience}

Phyllis O'Connor Susan Wehmeyer Susan Weldon

\section{INTRODUCTION}

Resource sharing through interlibrary loan has allowed libraries to offer access to information far beyond the walls of any one institution. Since the first interlibrary loan transaction, however, librarians have worked to reduce borrowing and lending costs and to improve delivery speed. The Ohio Library and Information Network (OhioLINK), in contract with Innovative Interfaces, Inc., is pushing the idea of resource sharing a step further.

OhioLINK's membership includes fifteen public universities, two private universities, 23 community and technical colleges and ${ }^{\text {the }}$ State Library of Ohio. Its goal is to position its member libraries for the future so that it is established as the information gateway of choice for users of OhioLINK libraries. To accomplish this, the

Phyllis O'Connor is Assistant Dean of University Libraries at the University of Akron in Akron, OH. Susan Wehmeyer is Head of Information Delivery Services at Fordham Health Sciences Library, Wright State University in Dayton, OH. Susan Weldon is Head of Information Delivery Services at Paul Laurence Dunbar Library, Wright State University in Dayton, OH.

[Haworth co-indexing entry note]: "The Future Using an Integrated Approach: The OhioLINK Experience." O'Comor, Phyllis, Susan Wehmeyer, and Susan Weldon. Co-published simultaneously in Journal of Library Administration (The Haworth Press, Inc.) Vol. 21, No. 1/2, 199S, pp. I 09-120; and The Future of Resource Sharing (ed: Shirley K. Baker, and Mary E. Jackson) The Haworth Press, Inc., 199S, pp. 109-120. Multiple copies of this article/chapter may be purchased from The Haworth Document Delivery Center [1-800-342-9678; 9:00a.m.-S:OO p.m. (EST)].

(C) 1995 by The Haworth Press, Inc. All rights reserved. 
network will cooperatively develop collections, offer a growing number of electronic resources to all member libraries, and improve the interlibrary loan of printed material across all institutions to the point that access is virtually equivalent to ownership. Tom Sanville, Director of OhioLINK, describes the project as a work in progress which may never be finished. He believes that as technology changes and improves, so will the design of the project.

The work on this project began in 1987, when the Ohio Board of Regents began investigating the possibility of creating a state-wide automated network so that resources could easily and efficiently be shared at the state level between academic libraries.

The network that the Board of Regents envisioned would use current future technology as a tool to improve library service. Successful implementation of this program would increase the research effectiveness and productivity of faculty and students throughout the state of Ohio.

In the Fall of 1989 the Request for Proposal for OhioLINK was issued, and eight vendors responded. Innovative Interfaces, Inc. (III \} was chosen in the Summer of 1990 as the vendor that could most effectively create the OhioLINK system. The committees that worked on the original proposal began working with III on the exact system configurations required to make the project work.

One of the first steps of this project was the installation of the Innovative Interfaces, Inc. integrated library system at each of the member institutions. Each local database was merged into a central catalog which was then made available for patron-initiated borrowing. The service, called online borrowing, offers patrons the opportunity to select materials from the catalogs of a growing number of institutions. The building of the central catalog struted with three libraries in August 1992, and new libraries have been added at the rate of approximately one per month. The patron online borrowing function was activated in January 1994.

OhioLINK online borrowing creates a natural link between the request process and the circulation function because the patron requires no intermediary to borrow from another library. The patron online borrowing service operates as follows:

From either a terminal in the library or a remote work station, the patron identifies an item in the shared catalog which is not available locally. Users can search the central catalog in two ways: by logging directly into the central catalog or by searching their local catalog and passing their search through to the central catalog.

The patron then places a request on the public catalog to borrow that item. (The current system design only accepts requests for books with item records.) The request is electronically delivered, through the central database, to the owning library.

A paging slip, which instructs staff to pull and ship the material to the patron's library, is generated at the owning library.

The material is checked out, prepared for delivery and shipped to the borrowing library. The borrowing library receives the material and sends an arrival notice to the patron.

The transaction is recorded and updated at each step of the process on the patron's record, the owning library's item record and in the OhioLINK central catalog. The goal is to complete the service, from request to delivery, in 48-72 hours. 
This article reviews how the planners and initial participants combine a patron-driven system with traditional interlibrary loan operations. It addresses the concerns and perspectives of administrators, managers and patrons, all of whom play important roles in the ongoing development of this network. Planners face issues relating to participation costs, the sharing of materials, workload and workflow management, training, and the future of interlibrary loan as a distinct operational unit.

\section{ADMINISTRATIVE PERSPECTIVE}

The concept of enhancing resource sharing through online borrowing provides administrators with a unique opportunity to expand library service, but it also presents them with major implica tions for their institutions' budgets. Some administrators are concerned about the effects of such a system on the independence of their library operations and the long-range effects of sharing their collections.

\section{Ownership and Independence}

OhioLINK planners envision a service that needs more than just cooperation and support from a diverse group of administrators. For the purposes of online borrowing, OhioLINK institutions need to function as one library with many branches. Administrators recognized the need to share more than just their online catalogs and agreed to share the bulk of their collections; however, in the early planning stages much emphasis was placed on individual ownership of books and collections. Fortunately, over the course of several years, the emphasis shifted from "my., books and "your" patrons to "our" collection and "our" patrons. Some planners even wondered whether the libraries had any reason to return material to the "owning" agency at all. Despite these thoughts, OhioLINK has not become one giant state library, even though all OhioLINK patrons do have access to all circulating collections. The acknowledged goal has been to think in terms of access rather than ownership.

\section{Cost Issues}

OhioLINK members made a commitment to develop services (e.g., patron online borrowing; access to electronic databases) which improved the cost efficiency and user effectiveness of statewide information services. The Ohio Board of Regents funds a portion of the costs for a central computer and Innovative Interfaces software at each institution; however, continued and additional funding is needed at each campus and through the OhioLINK central budget to meet the long-range goals of the project. Several funding models that rely on resources from OhioLINK, local institutions, and grants in various combinations are planned. The major fmancial advantage of OhioLINK, however, will be the opportunity to bring about efficiencies in the use of existing funds by economies of scale, improved processing efficiencies and reallocation of existing budgets. The major ongoing expense to local sites for improved delivery of materials will be the cost of staff time to pull, process, and ship materials. Improving efficiency will require more staff than most libraries have dedicated to the task.

OhioLINK has already offset some of the expense of improved service by centralizing common costs such as courier service, user guides, and publicity materials. The delivery service is an excellent example of how the network achieved economies of scale not attainable by individual 
institutions. OhioLINK locations were joined by a ground carrier system through regional hubs that offered twenty-four hour delivery between sites at a unit cost far less expensive than direct shipment methods previously used by member libraries. An initial sample placed the cost at about one dollar for each delivery to a destination.

Several additional cooperative ventures are anticipated to economize the member institutions' budgets further. When the patron borrowing function is made available for journal requests, a subsystem will centrally track usage and automatically determine copyright compliance fees. The staff time previously devoted to this task can then be reallocated. OhioLINK is also considering funding the purchase of "self check-out" stations at library locations where circulation desk staff time can be freed for other tasks. As the project progresses, improved access to other libraries' collections and an efficient collection development plan may allow administrators to make reallocations from the materials budget.

One cost issue which has not been decided is whether net lenders will be compensated for their participation. Traditional financial agreements involving interlibrary loan have emphasized balanced reciprocal borrowing. Institutions that could not supply as much as they borrowed generally paid a fee for the loan. During the first year of patron online borrowing, OhioLINK plans to analyze lending statistics and consider a formula for distributing funding based on use. Participants resolved some cost issues related to resource sharing in administrative planning sessions. After long deliberations characterized by cooperation and consensus building, OhioLINK circulation policies were formally adopted by all members. All administrators agreed to a standard fine of fifty cents per day for overdue materials borrowed online. They also agreed to maximum fines for OhioLINK patrons who chose to borrow in person from a member library. In both cases, the lending library agreed to collect and retain these fines. The participants agreed that the borrowing library would pay the lender a standard replacement fee and processing charge for lost material. Still under discussion, however, is a plan to reduce invoicing between institutions by accounting for replacement fees on a quarterly or annual basis. To improve the recovery of long overdue items, the libraries have cooperated with student registration blocks or other available sanctions as needed.

\section{THE OPERATING PERSPECTIVE}

Local managers brought different concerns to the planning and implementation of online borrowing. They were primarily interested in workload, workflow, and training issues. They were also concerned about the impact of online borrowing on the future of interlibrary loan.

\section{Workload and Workflow}

Management staff were deeply involved in the planning process. The OhioLINK Inter-Campus Services Committee, which consisted largely of middle management staff from interlibrary loan and circulation units, was assigned the task of designing and implementing a statewide circulation system that would deliver requested materials to patrons in 48 to 72 hours. As a result, these managers learned early that successful online borrowing systems in other states had produced increased interlibrary traffic. Although managers were prepared for the need to revise workflow patterns, they had to maintain a flexible approach to the problem, because the planning process was not sufficiently detailed to allow pre-planned workflow schemes. Predictions still remain uncertain for when and at what level the workload will stabilize. Approaches to the increased workload have varied, with member libraries employing different methods to shift the 
verification and ordering from library staff to patrons. The University of Akron screens all incoming interlibrary loan book requests and, when possible, uses OhioLINK online borrowing to complete transactions rather than place requests via OCLC. Akron returns the interlibrary loan form to the patron with a note encouraging the use of the OhioLINK system. Bowling Green State University returns interlibrary loan book requests to the patron when the material is available through OhioLINK with instructions to directly request the material. Wright State University advertises the new service when a patron receives an item through interlibrary loan that is available through OhioLINK. While many institutions have refrained from publicizing traditional interlibrary loan services, this new service is heavily publicized throughout the state. Library staff frequently direct patrons to the new service, but the system generally sells itself.

A related issue is the inability of the system to distribute lending requests evenly among the institutions; this is because the borrower currently selects the lending library. As a result, the participants cannot structure a reciprocal balance. Administrators at the University of Akron are understandably concerned that as the first institution listed in the holdings display, they will receive a disproportionate number of OhioLINK requests, just as they already do with OCLC lending. A system-generated algorithm to balance lending was implemented in the Fall of 1994. Although patrons have assumed a portion of the work required to process an interlibrary loan, and patron online borrowing is less staff intensive, distribution of staff workload remains inevitably uneven. In the early stages of implementation, enthusiastic, capable staff frequently volunteered to carry a disproportionate amount of the load. As the project evolves, experienced staff will be able to take advantage of new opportunities for advancement or development which will result from restructured interlibrary loan operations. They will also play a key role in helping others adjust to changes in operation.

\section{Training}

Much of the initial staff training was through hands-on experience. On several occasions, formal training sessions were conducted by Innovative Interfaces, Inc. Participants often uncovered programming problems and changes were made by III before the training session was completed. A training database is planned, but all initial testing and training used real item records. Before testing the system, representatives agreed on standard operating procedures including: loan periods, fines, patron blocks, replacement costs, patron types and item types.

Staff at Miami University, Wright State University and University of Cincinnati gamely tested the online borrowing system before offering it to the public. Managers at these sites found items to request, created test patron accounts, tracked requested items and made printouts of everything that went right or wrong. Testing lasted nine months with no real books changing hands during the first six months. After these initial participants were trained, a partner system was implemented for testing and training. As new sites were added, each new library was paired with an experienced library. This system has been very effective.

After training key librarians at each site, only local staff training issues remained. Each OhioLINK library developed unique training methods. For example, the thirteen libraries affiliated with Wright State University used a separate but similar system III developed for intrainstitutional requests. Circulation and automation services staff created screen prints and handouts that documented every step of the process. Staff placed test requests in September 1993. In November 1993, the library offered the local request function to patrons. It was an immediate success and gave staff and patrons experience with online borrowing before OhioLINK patron online borrowing was implemented. 


\section{Future of the Interlibrary Loan Unit}

Throughout the planning and implementation of this new resource sharing model, the interlibrary loan librarians were concerned about what the final role of their units would be in the new system. They continue to recognize that the need for their familiar services is diminishing. Online borrowing relies upon the patron to verify the item to borrow, select the lending institution, and place the request. The computer will soon pick the item and track copyright and use statistics. Much of the rest of the borrowing and lending process can be easily folded into circulation operations or shipping/receiving units.

When the process is fully operational at all OhioLINK institutions, the management of requests through interlibrary loan may change based on the number of items requested using either online borrowing or OCLC. During the first quarter of 1994, with online borrowing available, OCLC interlibrary loan requests between OhioLINK libraries increased three percent. It is obvious that OhioLINK has not, so far, alleviated any of the demand for traditional interlibrary loan services. Interlibrary loan traffic patterns, however, seem to be changing. An examination of book requests being sent by the University of Akron's interlibrary loan staff shows a dramatic shift since the implementation of patron-initiated borrowing. In January 1994, the University of Akron borrowed 162 books from other OhioLINK libraries using OCLC. In March 1994, that figure was reduced to 56. By May 1994, only 29 book requests were sent. During this same five-month period, the University of Akron's patrons requested 3,570 books over the OhioLINK network. While book borrowing decreased, journal requests and total lending temporarily increased for several reasons. First, although patrons could see journal holdings, they could not place direct requests; they needed to use interlibrary loan to request articles. Second, a number of institutions have access to the OhioLINK online catalog but are not yet able to use the patron online borrowing service. Their requests must also be processed through interlibrary loan. When joumal requests are available online, and as access to the request system grows, lending via intraOhioLINK interlibrary loan is also expected to decline. Even so, OhioLINK does not expect to satisfy all patron needs through online borrowing. The need to integrate the two processes into the organization of the library remains.

As the processes evolve, each OhioLINK library continues to struggle with the integration of online borrowing into existing organizational models. Organizational units dedicated to interlibrary loan operations have been placed in many branches of the library hierarchy. In the past, reporting structure often depended more on who was qualified to manage ll...L activities in a particular library rather than on where interlibrary loan logically fit within the organizational structure. In response to the demands of online borrowing, some OhioLINK libraries have already combined their circulation and interlibrary loan departments into one new department that deals with both functions. Others have maintained separate departments, but moved them under the same management structure, so that interlibrary loan and circulation are part of the same division.

In time, the nature of patron online borrowing may spur the development of team management in some member institutions. OhioLINK managers provide a role model for this approach by solving the inevitable glitches in a team effort. Library representatives to OhioLINK central administration continue to meet regularly to discuss issues, design testing procedures, and address other special needs. Several e-mail listserv groups have extended the avenues of communication. For example, a listserv connects the OhioLINK testers to Innovative Interfaces staff and programmers who scan problem reports and offer solutions. 
Managers may also use a team approach to deal with the day-today practical operations of this new service while staff adjust to changes in workflow patterns, job descriptions and the stress that accompanies change. As clear departmental lines fade, it is necessary for all public service staff to have working knowledge of the online borrowing service. When a patron asks at the reference desk how to place a request on the public catalog, who will provide the instruction, simple though it is? When a patron comes to the circulation desk with the same question, will the instruction be the same? If updates to patron records were always a duty of the circulation department, but the interlibrary loan staff need updated records to fill requests, whose job will it be? The most successful online borrowing operations will involve staff with expertise in automation, traditional interlibrary loan, circulation, reference, shipping, and problem solving. If these staff do not work in the same unit or team, they must, at minimum, have a sense of working toward a common goal.

\section{PATRON PERSPECTIVE}

Generally, patrons have welcomed this new service. It is easy to use. Searches performed at the local catalog are passed through to the central catalog with a touch of a single key. Patrons request items by simply entering their name and university identification number. There are no forms to fill out, no service lines to wait in. The service is so easy to use that very little, if any, formal user education is needed; OhioLINK-issued brochures and bookmarks are sufficient teaching aids. Patrons like to use OhioLINK patron online borrowing since delivery is faster than most traditional interlibrary loan service.

Some universities have traditionally charged a fee for interlibrary loan services, and many have restricted this service to graduate students and faculty members. However, OhioLINK online borrowing of books is offered without charge to every undergraduate and graduate student, faculty and affiliated faculty, staff, and courtesy card holder at every OhioLINK institution. Predictions that graduate and faculty use of the online borrowing function would far exceed undergraduate use have proven untrue. Figures for the ftrst five months of OhioLINK borrowing show that of the over 24,000 requests placed across the system that graduate students borrowed 9,529 books (38.2\% of the total traffic); that undergraduates borrowed 7,915 (31.7\%); and that faculty borrowed 5,301 (21.2\%). The remainder of the requests $(8.4 \%)$ were placed mostly by staff.

Although it is too early for real statistical analysis of changing patron behavior, anecdotal evidence of such change exists. A graduate assistant at an OhioLINK site cheerfully selected books from another OhioLINK library to avoid searching the stacks. This same graduate assistant located journal titles at OhioLINK libraries and placed her requests through Interlibrary Loan to avoid the cost involved in photocopying at her institution. "This way," she reported, "I can come back in a few days, and pick up my photocopies and books all in one place, and I'll be all set." Some patrons were observed "hedging their bets" to secure a particularly popular book. They requested ALL available copies "just to be sure." Because the online catalog encourages "electronic browsing," many patrons request books just to examine the index or table of contents. Unlike the familiar and unchanging card catalog of yesteryear, versions of computer software enter and leave the library as though through a revolving door. As a result, patrons of the 1990s learn to adapt very quickly to change. As the above examples illustrate, OhioLINK patrons have 
been quick to accept and exploit the changes and opportunities created by patron online borrowing.

\section{CONCLUSION}

Futurists envision researchers in the twenty-first century, browsing topical "libraries" at will, while a computer in direct interface with the human brain identifies relevant reading material. A likely article is instantly downloaded to a small electronic "book." When a question arises in the lab, a quick link to the International Library provides the answer. Although such wonders exist only in science fiction books today, expanding consumer demand for information may drive technology to make fiction reality before we know it.

Despite the lure and glamour of the future, we still live in a time when books and journals are published in print; when libraries must buy individual copies and subscriptions; and when librarians must cope with copyright guidelines, reciprocal agreements, and lending policies. Obtaining resources from outside the walls of the library, whether under the banner of interlibrary loan, document delivery or resource sharing, is the reality of today.

Through OhioLINK, member institutions are addressing their present needs while developing their roles in the future information industry; they are becoming a connective gateway offering valuable access and convenient packaging at library network costs; they plan to provide full-text databases linked to citation databases; they also plan to find alternative technologies for document delivery (e.g., patron online borrowing of journal articles and UMI "Power Pages" article delivery). Integrating online borrowing with interlibrary loan is just the first step in an ongoing process. It is a step towards bridging the gap from today to the future. 